GA-A16287

(E-117-830)

\title{
FISSION-PRODUCT RELEASE FROM TRIGA-LEU REACTOR FUELS
}

by

N. L. BALDWIN, F. C. FOUSHEE, and J. S. GREENWOOD

$$
\text { AT03-76 SF70064 }
$$

Partially funded under Contract Agreement EY-76-C-03-0167

Project Agreement 64 for the San Francisco Operations Office

Department of Energy

DATE PREPARED: NOVEMBER 1980

\section{GENERAL ATOMIC COMPANY}




\section{DISCLAIMER}

This report was prepared as an account of work sponsored by an agency of the United States Government. Neither the United States Government nor any agency Thereof, nor any of their employees, makes any warranty, express or implied, or assumes any legal liability or responsibility for the accuracy, completeness, or usefulness of any information, apparatus, product, or process disclosed, or represents that its use would not infringe privately owned rights. Reference herein to any specific commercial product, process, or service by trade name, trademark, manufacturer, or otherwise does not necessarily constitute or imply its endorsement, recommendation, or favoring by the United States Government or any agency thereof. The views and opinions of authors expressed herein do not necessarily state or reflect those of the United States Government or any agency thereof. 


\section{DISCLAIMER}

Portions of this document may be illegible in electronic image products. Images are produced from the best available original document. 
This report was prepared as an account of work sponsored by an agency of the United States Government. Neither the United States Government nor any agency thereof, nor any of their employees, makes any warranty, express or implied, or assumes any legal liability or responsibility for the accuracy, completeness, or usefulness of any information, apparatus, product, or process disclosed, or represents that its use would not infringe privately owned rights. Reference herein to any specific commercial product, process, or service by trade name, trademark, manufacturer, or otherwise, does not necessarily constitute or imply its endorsement, recommendation, or favoring by the United States Government or any agency thereof. The views and opinions of authors expressed herein do not necessarily state or reflect those of the United States Government or any agency thereof. 
GA-A16287

(E-117-830)

This book was prepared as an eccount of work sponsoros by asency of tha United States Govetnment.

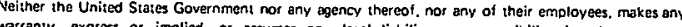
complezeness, ar usefulness of ass ines any layal hability or responsibiliny tor the accuracy. represents that its use would not intringe privately ownet rights. Reference herin 10 any soectic commercial product, orocess, of service by irade name, trademark, manufacturo, or otherwise dow

not necessarily constitute of imply its endorsement, recommendation, or fovoring by the Unires States Government or any agency thereot. The views and opinions of authors expressed herein do nol

FISSION PRODUCT RELEASE FROM TRIGA-LEU REACTOR_FUELS

\author{
GA-A--16287
}

by

DE82 007218

N. L. BALDWIN, F. C. FOUSHEE, and J.'S. GREENWUODD

Partially funded under .

Contract Agreement EY-76-C-03-0167

Project Agreement 64

for the San Francisco Operations Office

Department of Energy

GENERAL ATOMIC PROJECT 3272

DATE PREPARED: NOVEMBER 1980 
CONTENTS

1. SUMMARY . . . . . . . . . . . . . . . . . . . 1

2. EXPERIMENTS ....................... . . . . . 4

2.1. Fission Gas Release Tests . . . . . . . . . . . . . 4

2.2. Postirradiation Anneal Tests . . . . . . . . . . . . 5

2.3. Thermal Cycling Tests . . . . . . . . . . . . . 9 9

3. RESULTS . . . . . . . . . . . . . . . . . . 11

3.1. Fission Gas Release Tests.............. 11

3.2. Postirradiation Anneal Tests . . . . . . . . . . . 17

3.3. Thermal Cycling Tests . . . . . . . . . . . . . 17

4. FISSION PRODUCT RELEASE CORRELATION . . . . . . . . . . . . 21

4.1. Recoil Release .................... 21

4.2. Diffusion Release ... . . . . . . . . . . . . 25

4.3. Effect of Experimental Conditions on High-Temperature

4.4. Effect of Uranium Particle Size on High-Temperature

Release.................... 33

5. CONCLUSIONS . . . . . . . . . . . . . . . . . 35

6. REFERENCES ....................... . . . . 37

\section{FIGURES}

1. Fractional release uf gaseous fission producto from TRIGA

fuel .......................... 3

2. TRIGA fuel specimen in simulated cladding........... . 7

3. Schematic of postirradiation annealing apparatus . . . . . . 8

4. Temperature dependence of fission gas release from TRIGA fuel . . 13

5. Phocographs of uranlun $\mathrm{X}$-ray distribution maps in TRICA
fuel specimens . . . . . . . . . . . . . . 16

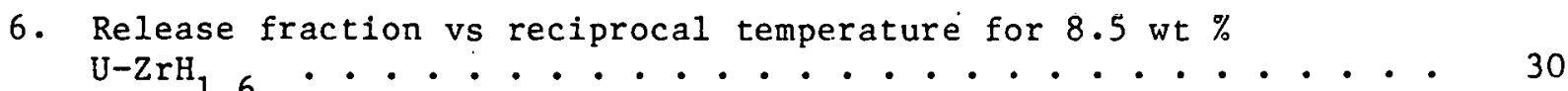

7. Release fraction vs reciprocal temperature for 30 wt \%

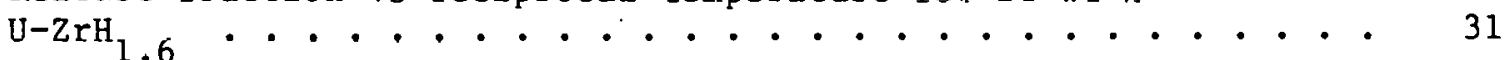

8. Release fraction vs reciprocal temperature for 45 wt $\%$

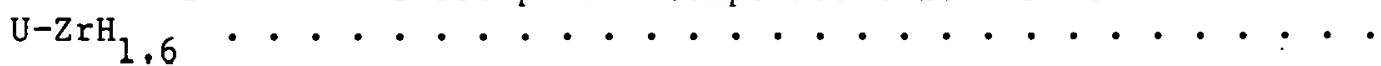




\section{TABLES}

1. Description of fuel samples tested ............. . 5

2. Results of fission gas release tests . . . . . . . . . . . 12

3. Summary of metallographic and microprobe examination . . . . . 14

4. Recoil, annealing, and total fission product release in postirradiation anneal experiment (uncorrected) . . . . . . . 18

5. Results of thermal cycling tests ... . . . . . . . . . 19

6. Recoll release measured in 1971 experiment . . . . . . . . . 23

7. Recoil release measured in current (1977-1978) experiment . . . 23

8. High-temperature release fraction corrected to infinite time . . 29 


\section{SUMMARY}

The release of fission products, both gaseous and volatile metals, from TRIGA fuel is important for the analysis of possible accident conditions related to reactor operation and the design of future TRIGA fuel systems. Because of present national concerns over nuclear proliferation, it has become clear that future reactor fuels will, of necessity, utilize low-enriched uranium (LEU, enrichment $<20 \%$ ). This will require increasing the total uranium loading per unit volume of the higher-loaded TRIGA fuels for the purpose of maintaining the appropriate fissile loading.

Because of these new developments, tests were conducted to determine the fractional release of gaseous and metallic fission products from typical uranium-zirconium hydride TRIGA fuels containing 8.5 to 45 wt \% uranium. These tests, performed in late 1977 and early 1978, were similar to those conducted earlier on standard ( 8.5 wt \% uranium) TRIGA fuels (Ref. 1).

The results of these tests on TRIGA-LEU fuel agree well with data from the similar, earlier tests on TRIGA fuel. The correlation used to calculate the release of fission products from TRIGA fuel is

$$
\psi=\left(1.5 \times 10^{-5}\right)+\left(3.6 \times 10^{3}\right)\left(\mathrm{e}^{-1.34 \times 10^{4} / \mathrm{T}}\right)
$$

where $\mathrm{T}=$ fuel temperature $\left({ }^{\circ} \mathrm{K}\right)$.

It is applicable for the high-uranium-loaded (TRIGA-LEU) fuels as well as the $8.5 \mathrm{wt} \% \mathrm{U}-\mathrm{ZrH}$ fuel for which it was originally derived. 
. This function (Eq. 1) is plotted in Fig. 1. The first term of this function is a constant for low-temperature release; the second term is the high-temperature portion, where above $400^{\circ} \mathrm{C}$ the controlling mechanism for fission product release is a migration or diffusion-like process, and the amount released is dependent on fuel temperature, time of irradiation, and isotope half-life.

The low-temperature release fractions have all been normalized to a standard ratio of fuel-clad gap to fuel diameter, although individual measurements were made with different geometries. The high-temperature release values are characteristic of fuel segments similar to the test samples where the surface-to-volume ratio is that associated with a diameter between 0.33 and 0.5 in.

The curve in Fig. 1 applies to a fuel element which has been irradiated for a sufficient length of time so that all fission product activity is at equilibrium. 


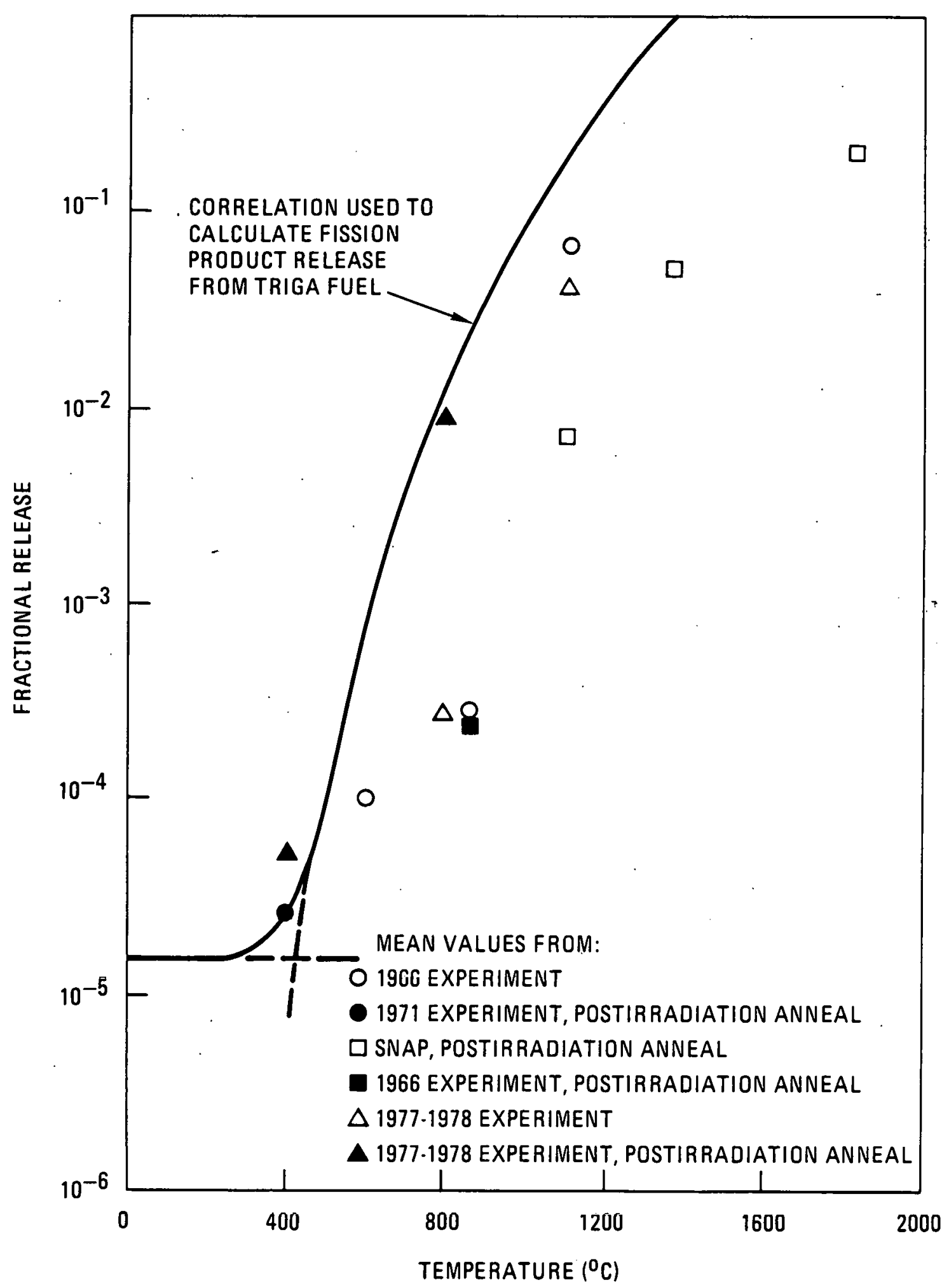

EL-3973

Fig. 1. Fractional release of gaseous fission products from TRIGA fuel. Experimental values above $400^{\circ} \mathrm{C}$ corrected to infinite irradiation. 


\section{EXPERIMENTS}

Measurements were made on appropriate fuel samples to provide information concerning the release of noble gas fission products and the volatile radionuclides of iodine. Tests were also conducted to determine the effects of thermal cycling on the physical integrity of TRIGA fuels. The following sections describe the work performed.

\subsection{FISSION GAS RELEASE TESTS}

Fission gas release measurements were made on prototypic specimens of TRIGA fuels from room temperature to $1100^{\circ} \mathrm{C}$ in the TRIGA King Furnace Facility (TKFF). The furnace facility, designed for TRIGA reactor in-core irradiation of fuels up to temperatures of $2000^{\circ} \mathrm{C}$, has been described previously (Ref. 2). The fractional releases, under steady-state operating conditions, of the gaseous nuclides of krypton and xenon were measured as a function of temperature by operating the TRIGA reactor at a low-power level and maintaining the desired fuel temperature through electrical. resistance heating. Clean helium was used to sweep the fission gases released during irradiation from the furnace into a standard gas collection trap for gamacounting, as described in Ref. 1. Irradiations of 30 min at each temperature were used for these tests.

Table 1 lists the fuel samples subjected to $R / B^{*}$ testing. The fuel specimens were approximately $12 \mathrm{~mm}$ ( $0.5 \mathrm{in.}$ ) in diameter by $50 \mathrm{~mm}$ (2 in.) in length. The uranium loading ranged from 8.5 to 45 wt \% with enrichments uf up lu 20\%. The 8.5 wt \% sample [same composicion as used in earlier tests (Ref. 1)] was uilized as a control sample to provide assurance that the test procedures used were comparable.

${ }^{*} \mathrm{R} / \mathrm{B}=$ ratio of fission gas release rate to birth rate in the fuel (uncorrected for container or cladding effects) 
TABLE I

DESCRIPTION OF FUEL SAMPLES TESTED

\begin{tabular}{l|c|c|c|c|c}
\hline $\begin{array}{c}\text { Sample } \\
\text { Designation }\end{array}$ & $\begin{array}{c}\text { Wt } \% \\
\text { Uranium }\end{array}$ & $\begin{array}{c}\text { Percent } \\
\text { Enrichment }\end{array}$ & $\begin{array}{c}\text { Length } \\
(\mathrm{mm})\end{array}$ & $\begin{array}{c}\text { Diameter } \\
(\mathrm{mm})\end{array}$ & $\begin{array}{c}\text { Weight } \\
(\mathrm{g})\end{array}$ \\
\hline E451-R1-A & 45 & 20 & 49.9 & 11.2 & 43.27 \\
E451-R1-B & 45 & 20 & 50.9 & 12.9 & 58.11 \\
E452-3 & 45 & 20 & $50.8(\mathrm{nom})$ & $12.7(\mathrm{nom})$ & 55.74 \\
D167-R3 & 30 & 0 & 49.5 & 11.0 & 38.14 \\
D167-R5-2 & 30 & 0 & 49.1 & 11.1 & 37.37 \\
D168-R1 & 45 & 0 & 49.4 & 11.1 & 44.79 \\
D168-R1-1 & 45 & 0 & 50.5 & 11.4 & 45.20 \\
$62177-R 2$ & 8.5 & 20 & 51.1 & 11.2 & 32.79 \\
$62177-R 3$ & 8.5 & 20 & 51.0 & 11.6 & 33.24 \\
\hline
\end{tabular}

Fission gas release measurements were made at room temperature, $400^{\circ}$, $800^{\circ}$, and $1100^{\circ} \mathrm{C}$. The data obtained showed larger than expected variations in release for samples of the same composition but of different manufacturing dates. Because of these variations, additional tests in the form of microprobe and metallography examination were performed. Samples were examined to determine if structural differences might be responsible for the wide range of release values observed.

\subsection{POSTIRRADIATION ANNEAL TESTS}

Postirradiation anneal tests were conducted on fuel samples to determine the release of fission product noble gases and volatile iodine radionuclides under conditions which could be similar to those which might exist if an irradiated element ruptures in air. However, neither of the temperatures investigated $\left(400^{\circ}\right.$ and $800^{\circ} \mathrm{C}$ ) are high enough to produce internal pressures necessary to rupture the clad. Fuel and clad temperatures would have to be in. the range of about $950^{\circ}$ to $1050^{\circ} \mathrm{C}$ for this to occur. The results do allow comparison between the fission product release under normal operation and under postoperation temperature excursions. It 
should be noted, however, that even though values from both types of tests are shown for comparative purposes in $\mathrm{Fig}$. 1, they actually represent two different processes. The fractional release values from the high-temperature irradiations are ratios of rates (release rate to birth rate), and these rates represent equilibrium conditions. The fractional release values for the anneal tests represent a ratio of the total number of atoms released during the anneal time (corrected to the time of irradiation termination) to the total number of atoms produced just prior to the anneal. Thus, this ratio is not a ratio of rates and is dependent on the irradiation and anneal times and the half-lives of the isotopes monitored. In this context, it is noted that the 1971 and 1977-1978 postirradiation anneal tests both used 3-hr anneal times vs a 1-hr anneal in the 1966 test. Doing a detailed analysis of all of these effects would take a much more complex model than presently exists.

In order to compare the results of this experiment with earlier work (Ref. 1), the methodology of the previous experiment was replicated. A sample of TRIGA fuel, approximately $12 \mathrm{~mm}(0.5 \mathrm{in}$.) in diameter, by $50 \mathrm{~mm}$ (2 in.) in length, containing U-235 was first irradiated in a sealed container in the TRIGA reactor to produce approximately $10^{14}$ fissions. The fuel sample was enclosed in a piece of stainless steel tubing material, with a radial gap of $0.125 \mathrm{~mm}(0.005 \mathrm{in.})$ to simulate the fuel-clad system. The tubing was not hermetically sealed around the fuel specimen but was merely held in place with plastic tape so that it could be readily removed. The sample appeared much as the photograph in Fig. 2 (from Fig. 4-1 of Ref. 1). The irradiation was done at ambient reactor pool temperature $\left(20^{\circ} \mathrm{C}\right.$ ) and remained in the reactor overnight to allow decay of short-lived activity prior to annealing. The sealed sample container was opened in a purge apparatus designed to open the irradiation container without loss of the fission gases released from the fuel during irradiation. The tubing was then removed prior to annealing.

The annealing apparatus is shown schematically in Fig. 3. The system is similar to that used in earlier studies (Ref. 1) and consists of a glass tube for containing the anneal sample, several activated charcoal traps for 


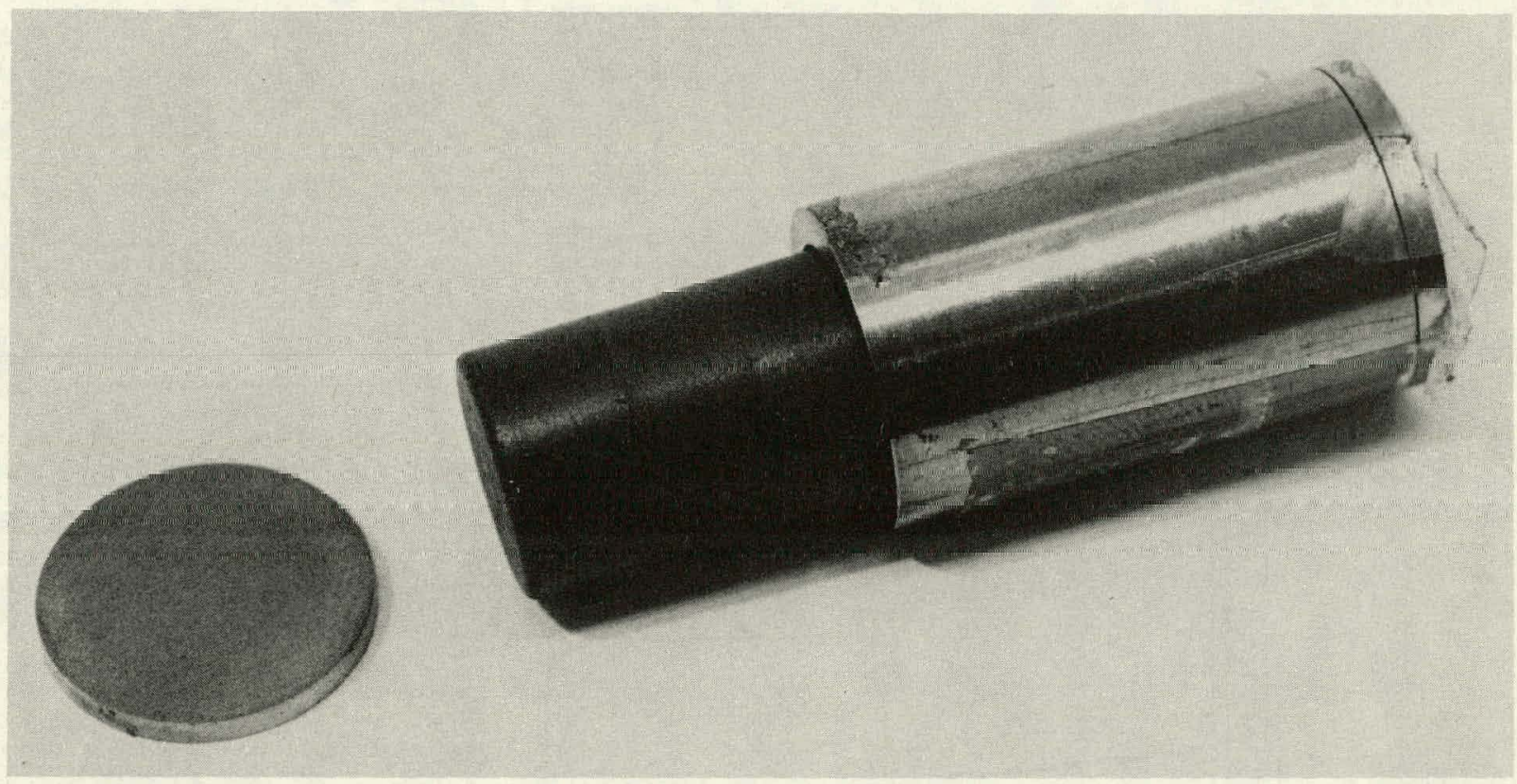

G90240

EL-3974

Fig. 2. TRIGA fuel specimen in simulated cladding 


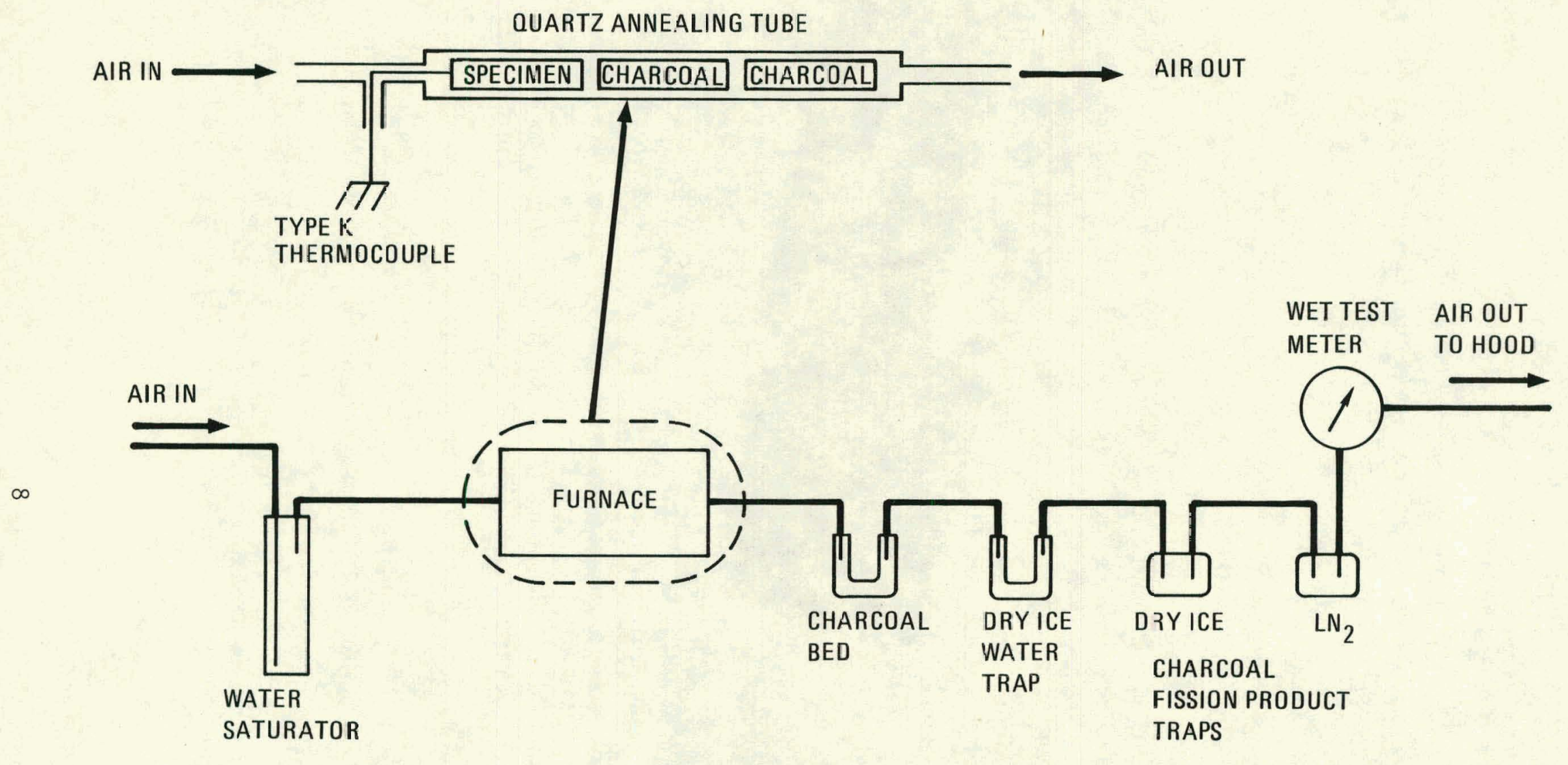

$E L-3975$

Fig. 3. Schematic of postirradiation annealing apsaratus 
collecting released iodine, and fission gas collection traps for collecting released krypton and xenon. Air, saturated with water, was passed over the sample at either $400^{\circ}$ or $800^{\circ} \mathrm{C}$ for $3 \mathrm{hr}$ at a constant flow of 0.5 liter/ min. The system flow was monitored using a wet test meter. A water knockout trap was installed just upstream of the 1iquid-nitrogen-cooled fission gas traps to prevent icing of the traps during the anneal period.

Upon termination of the anneal, the system was disassembled for fission product analysis. The furnace tube was leached in nitric acid to remove any activity adhering to the surface. The charcoal, fission gas, and water traps and the furnace tube leach solution were all gamma-counted to determine the distribution and total fission product release from the fuel specimen.

The released activity was then compared with the total sample inventories as determined by gamma-counting the fuel specimen after irradiation. Several isotopes such as I-133 or $B a-140$ or La-140 are accurate indicators of the number of fissions which have occurred in a sample. Thus, the postirradiation annealing experiment was utilized to monitor the release of both semivolatile and gaseous radionuclides from TRIGA fuel specimens. Specifically, the isotopes I-133, I-135, Xe-135, and $\mathrm{Kr}-85 \mathrm{~m}$ were monitored. The recoil fraction was obtained from the purge apparatus and the diffusional release (gas phase and/or bulk diffusion) from the anneals conducted at $400^{\circ}$ and $800^{\circ} \mathrm{C}$.

\subsection{THERMAL CYCLING TESTS}

The physical stability of TRIGA fuels of high uranium content was studied by subjecting fuel samples to a large number of thermal cycles. These tests were done during the fission product release tests because they utilize some of the same test equipment. Specimens of the same physical dimensions as described in Section 2.1 and a uranium content of $4 \overline{5} \mathrm{wt} \%$, $20 \%$ enrichment were thermally cycled between $500^{\circ}$ and $725^{\circ} \mathrm{C}$ for up to 100 cycles. The physical dimensions of the fuel samples were measured prior to cycling and at the end of every 25 cycles. The test was conducted first 
without a neutron field and then repeated in-pile at a flux of approximately $2 \times 10^{12} \mathrm{n} / \mathrm{cm}^{2}-\mathrm{sec}$. The temperature cycling was performed in a standard TRIGA King furnace purged continuously with clean helium.

The dimensional change of the fuel sample was monitored by measuring the length and the diameter of the cylinder of uranium-zirconium hydride several times at the end of each cycling period. Measurements were obtained using a Mitutoyo slide micrometer accurate to $0.01 \mathrm{~mm}$. In addition, weight losses were measured to determine the possible loss of hydrogen during cycling. 


\section{RESULTS}

\subsection{FISSION GAS RELEASE TESTS}

Six TRIGA fuel samples were tested in the TKFF from room temperature up to $1100^{\circ} \mathrm{C}$ to determine the fission gas release temperature dependence. The resulting data, given in Table 2 , consist of $R / B$ values for the noble gas isotopes $\mathrm{Kr}-85 \mathrm{~m}, \mathrm{Kr}-87, \mathrm{Kr}-88$, and $\mathrm{Kr}-89$. The temperature-dependent release data for $\mathrm{Kr}-85 \mathrm{~m}$ are plotted in Fig. 4 for the samples studied. Included in Fig. 4 is the curve representing the fission product release correlation (Eq. 1) based on data obtained earlier for standard $8.5 \mathrm{wt} \%$ uranium (20\% enriched) fuel samples (Ref. 1).

The uncorrected data, in general, show consistent, although somewhat higher, release than that found in the earlier studies for temperatures up to $400^{\circ} \mathrm{C}$. In contrast, the values at $1100^{\circ} \mathrm{C}$ show substantial variation even for fuel samples of the same composition. An example is the order of magnitude difference in release between the 30 wt \% samples (shown as the open and filled circles in Fig. 4). The 45 wt \% samples show a similar behavior and are represented by the open, partially filled, and completely filled triangles in Fig. 4. However, the data at $1100^{\circ} \mathrm{C}$ were all found to be the same as or less than the release obtained for the 8.5 wt \% samples studied earlier (Ref. 1). A sample of reference 8.5 wt \% uranium-containing fuel was tested along with the higher wt $\%$ samples. The results shown by the filled squares in Fig. 4 confirm the early 8.5 wt \% data represented by the curve.

Efforts to determine the cause for the large variations observed in the $\mathrm{Kr}-85 \mathrm{~m} \mathrm{R} / \mathrm{Bs}$ for the higher wt \% samples consisted of both metallographic and microprobe examination of the same fuel samples used in the fission gas release tests. Table 3 describes the results of these tests. It is apparent from the metallographic examination, shown in column 6 of Table 3, that the visual variations between samples do not correspond to 
TABLE 2

RESULTS OF FISSION GAS RELEASE TESTS

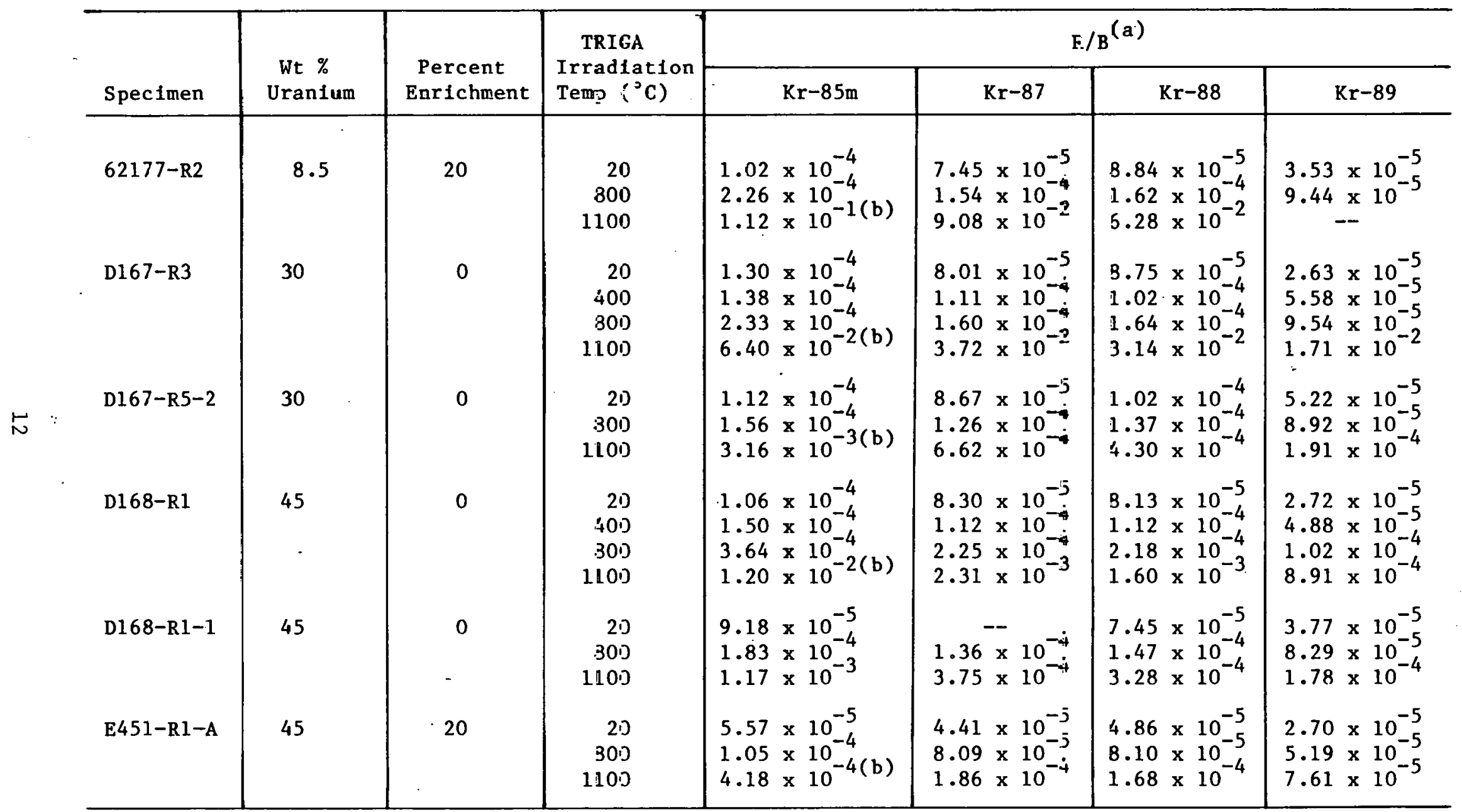

(a) $R / B=$ ratio of fission gas release rate to birth rate in the fuel (uncorrected for container or cladding effects). Values have been carrected to equilibrium irradiation tine.

(b) Average of two measurements 


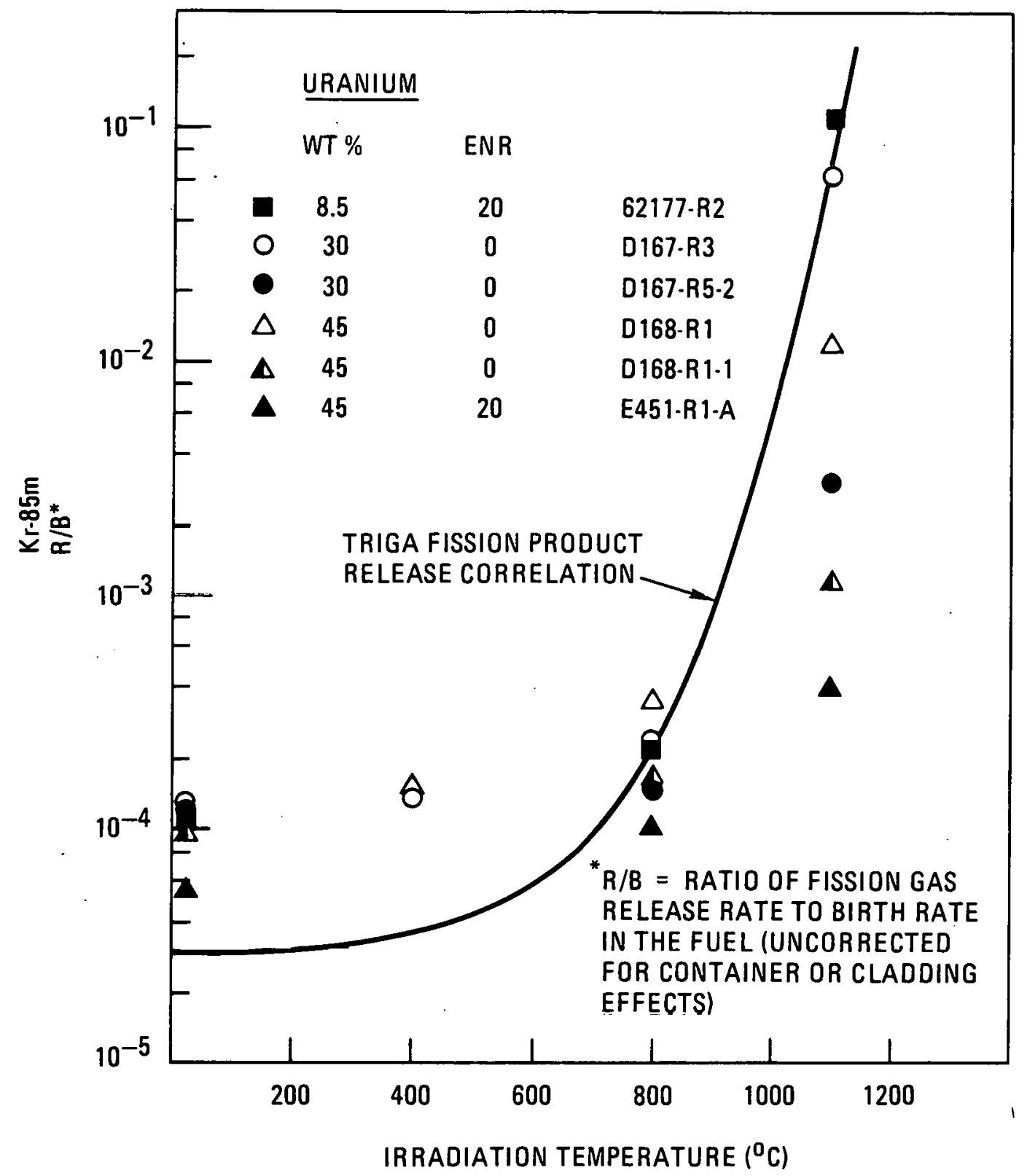

$E L-3976$

Fig. 4. Temperature dependence of fission gas release from TRIGA fuel 
TABLE 3

SUMMARY OF METALLOGRAPHIC AND MICROPROBE EXAMINATION

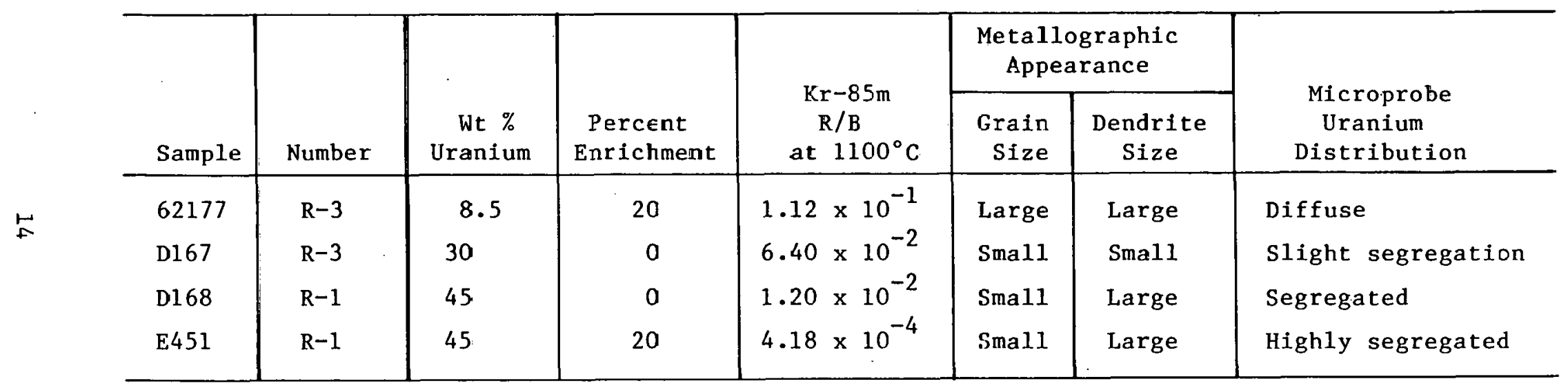


the observed increases in fission gas release. All four samples studied show some degree of characteristic dendritic structure. However, no obvious correlation could be made between the fission gas release values shown in column 5 of Table 3 and observable structural differences using metallographic techniques. Microprobe examination did, however, reveal substantial differences, as shown in Fig. 5. Figure 5 contains photographs of $X$-ray maps for uranium distribution in the fuel samples studied. The photographs show the relative uranium concentration near a zirconium hydride dendrite in the $30 \mathrm{wt} \%$ and $45 \mathrm{wt} \%$ cases. The dendrite appears as the cross-shaped void in the photographs for the higher wt $\%$ fuel. The photographs are all 100X magnifications of the samples studied. The highest-releasing sample, containing $8.5 \mathrm{wt} \%$ uranium, was found to have relatively uniform dispersal of uranium throughout the matrix (uranium particle size < 1 micron). On the other hand, uranium was found to concentrate at the $\mathrm{ZrH}$ dendrite boundaries as the uranium content was increased. This is evident in the distribution photographs shown in A ( $8.5 \mathrm{wt} \%)$, B (30 wt \%), and D ( 45 wt \%) of Fig. 5. The uranium segregation and concentration at the boundaries appear to increase with increasing wt \% uranium (concentration thicknesses of up to $\sim 5$ microns).

Comparing C and D of Fig. 5, one can also see an obvious difference between the uranium concentration at the boundaries in samples of the same composition. The photographs were taken of two samples containing 45 wt \% uranium but manufactured at different times. The sample in $D$ was enriched to $20 \%$ with $\mathrm{U}-235$, whereas the sample in $\mathrm{C}$ was made from natural uranium. The uranium appears to be less concentrated in $\mathrm{C}$, which also gave a much higher fission gas release value (factor of 30 higher) than did the sample represented in D. Thus, it is apparent that some physical parameter such as temperature (i.e., sample heating and cooling rates during manufacturing) must also be involved in the segregation phenomenon. 
A

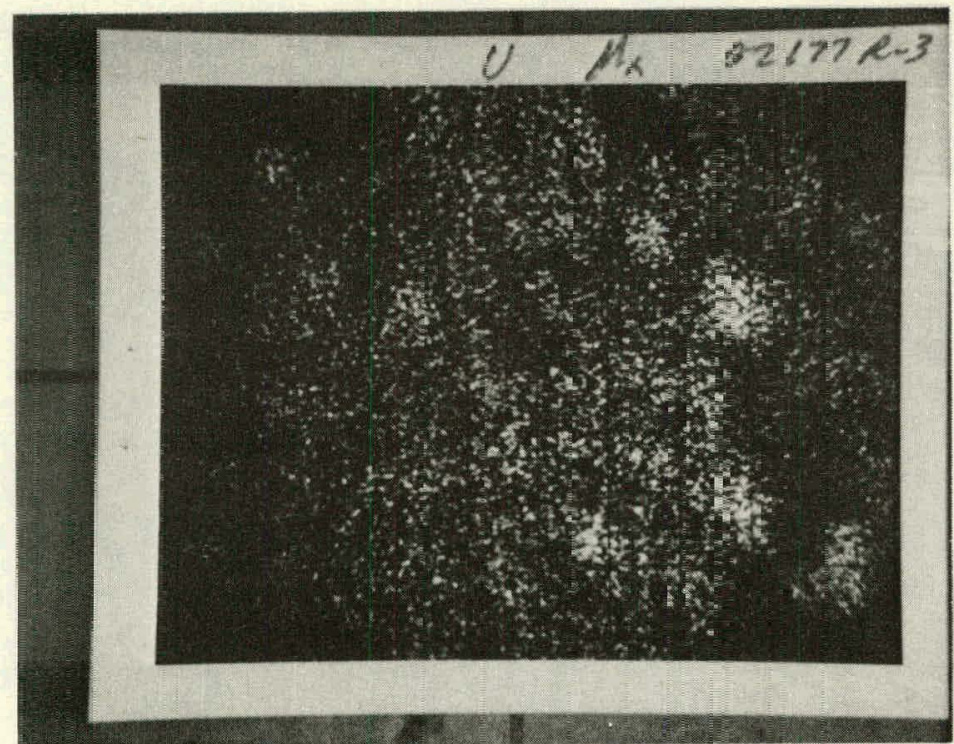

เே

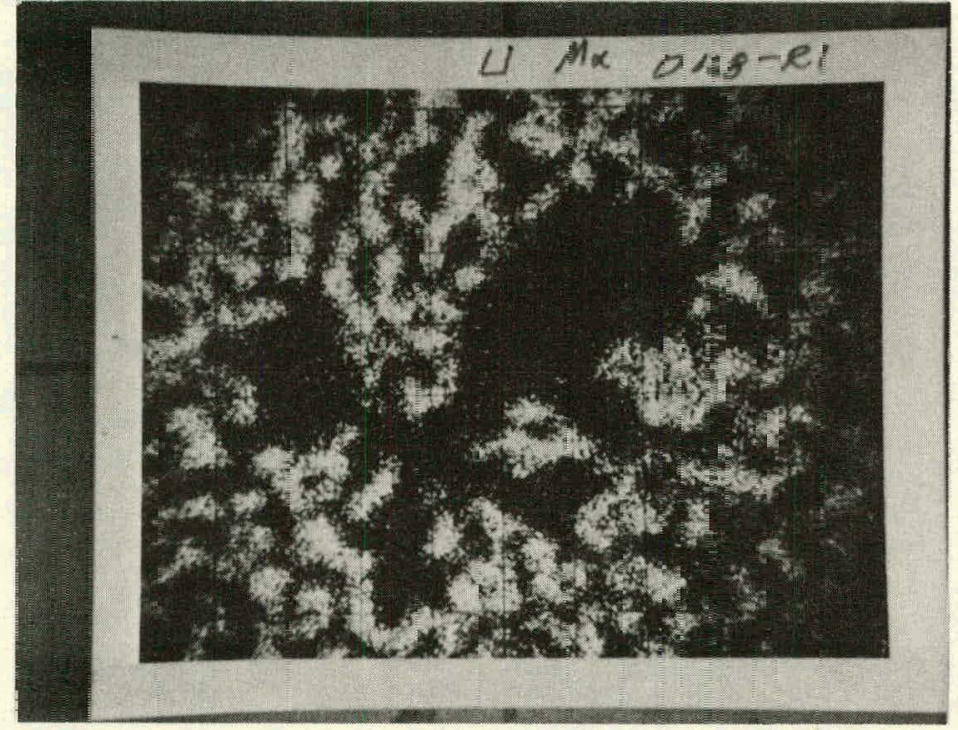

B

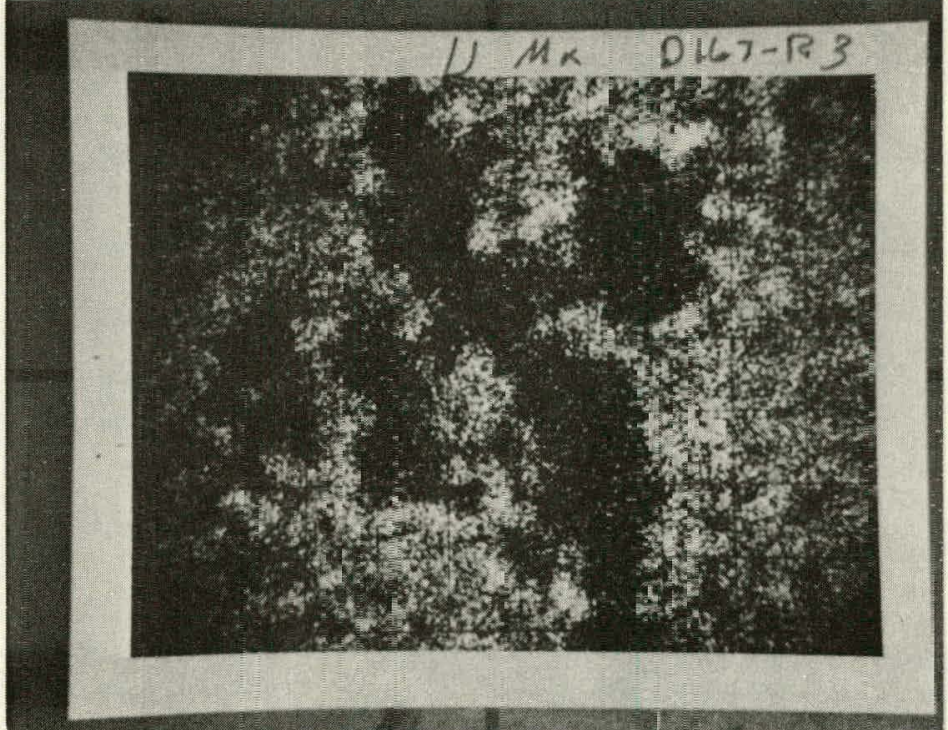

D

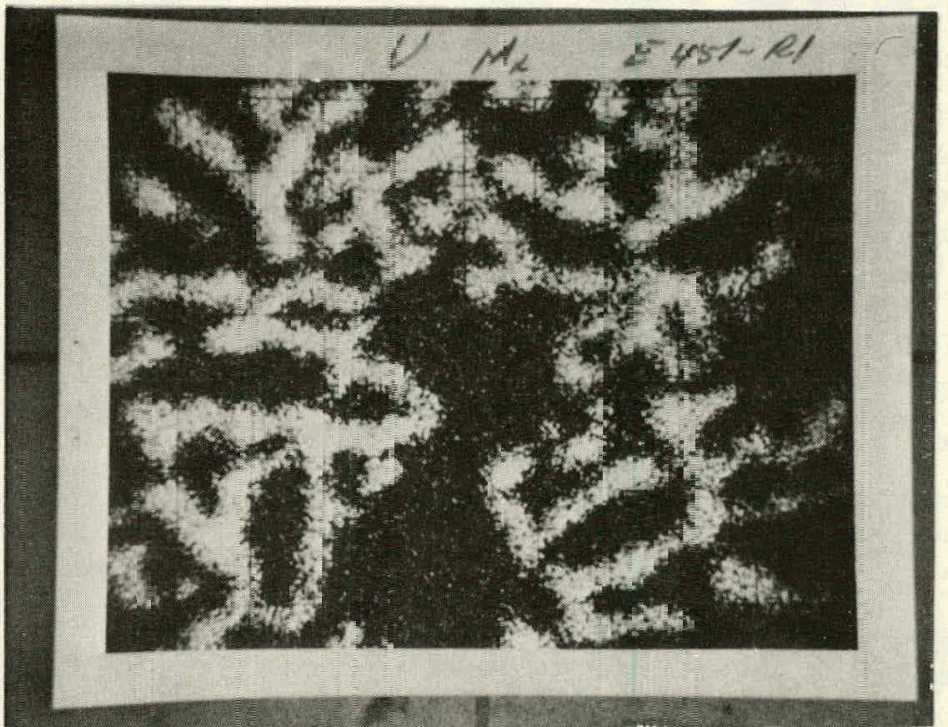

EL-3479

Fig. 5. Photographs of uraniu $X$-ray distribution maps in TRIGA fuel specimens: (A) 8.5 wt $\%, 20 \%$ enriched, (B) $30 \mathrm{wt} \%$, (C) 45 wt \%, and (D) 45 wt $\%$, $20 \%$ enriched (10-micran grid lines, 100-micron photo width! 


\subsection{POSTIRRADIATION ANNEAL TESTS}

Samples E45l-Rl-A and E452-3, each containing 45 wt \% uranium (20\% enriched), were used in the postirradiation anneal tests at $400^{\circ}$ and $800^{\circ} \mathrm{C}$, respectively. The results are given in Table 4. The data in Table 4 for $400^{\circ} \mathrm{C}$ show both the recoil and the anneal release fractions for $\mathrm{Kr}-85 \mathrm{~m}$, $\mathrm{Xe}-133, \mathrm{Xe}-135, \mathrm{I}-133$, and $\mathrm{I}-135$. The recoil fraction was obtained by determining the fission product release to the sample container during irradiation. The anneal fraction was obviously obtained from the release observed during thermal annealing tests. Included in Table 4 are total release values found for the standard 8.5 wt $\%, 20 \%$ enriched fuel sample studied earlier. The recent $400^{\circ} \mathrm{C}$ anneal release values are for the most part higher than the previous data. The isotopes $\mathrm{Xe}-135$ and I-135 in particular were both observed to be higher by factors of 4 and 7 , respectively. The other isotopes observed were within a factor of 2 of the earlier data. The effect of increased uranium loading in the TRIGA fuel was a corresponding increase in release under anneal conditions for a temperature where the temperature-dependent diffusion-like process is just beginning to be the dominant release mechanism. At an $800^{\circ} \mathrm{C}$ anneal temperature, the release fraction was somewhat larger than that in standard irradiation conditions, but the release value does fall below the value given by the correlation for TRIGA fuel in Eq. 1 .

\subsection{THERMAL CYCLING TESTS}

Thermal cycling tests from $500^{\circ}$ to $725^{\circ} \mathrm{C}$ were performed on fuel specimen E451-R1-B. The specimen, containing 45 wt \% uranium ( $20 \%$ enriched), is described in Table 1 . The sample was first cycled 100 times without neutrons and then cycled 32 times in a neutron flux of $\sim 4 \times 10^{12} \mathrm{n} / \mathrm{cm}^{2}-\mathrm{sec}$. During cycling tests in the absence of neutrons, the specimen was removed from the inert-gas-purged furnace every 25 cycles for dimensional and weight measurements. The resulting data are given in Table 5. The only observable change in the sample after 100 cycles was a slight decrease in weight. The dimensional changes were within the error of measurement and were considered insignificant. 
TABLE 4

RECOIL, ANNEALING, AND TOTAL FISSION PRODUCT RELEASE -N POSTIRRADIATION ANNEAL EXPERIMENT (UNCORRECTED)

\begin{tabular}{|c|c|c|c|c|c|c|c|}
\hline \multirow{2}{*}{$\begin{array}{c}\text { Wt \% } \\
\text { Uranium }\end{array}$} & \multirow[b]{2}{*}{$T \in m p\left({ }^{\circ} \tilde{S}\right)$} & \multirow{2}{*}{$\begin{array}{l}\text { Release } \\
\text { Mode }\end{array}$} & \multicolumn{5}{|c|}{ Fractional Release } \\
\hline & & & $. K r-85 n$ & $\mathrm{Xe}-133$ & $\mathrm{Xe}-135$ & $I-133$ & $I-135$ \\
\hline 45 & 400 & Recoil & $4.59 \times 10^{-5}$ & $9.62 \times 10^{-6}$ & $3.42 \times 10^{-5}$ & $2.23 \times 10^{-7}$ & -- \\
\hline 45 & 400 & Anneal & $6.16 \times 10^{-5}$ & $1.30 \times 10^{-4}$ & $5.22 \times 10^{-4}$ & $3.05 \times 10^{-5}$ & $2.27 \times 10^{-5}$ \\
\hline 45 & 400 & Total & $1.07 \times 10^{-4}$ & $1.40 \times 10^{-4}$ & $5.56 \times 10^{-4}$ & $3.07 \times 10^{-5}$ & $2.27 \times 10^{-5}$ \\
\hline 8.5 & 400 & $\operatorname{Total}^{(a)}$ & $1.27 \times 10^{-4}$ & $6.46 \times 10^{-5}$ & $1.33 \times 10^{-4}$ & $1.93 \times 10^{-5}$ & $3.04 \times 10^{-6}$ \\
\hline 45 & 800 & $\operatorname{Tota1}(b)$ & $4.80 \times 10^{-3}$ & $5.88 \times 10^{-3}$ & $2.02 \times 10^{-2}$ & $1.08 \times 10^{-2}$ & $7.20 \times 10^{-3}$ \\
\hline
\end{tabular}

(a) Average values obtained in earlier studies, as reported in Ref. 1, for a 8.5 wt $\%$, $20 \%$ enriched fuel sample

(b) Total value is approximately equal to the anneal value, as recoil is an insignificant contribution with $800^{\circ} \mathrm{C}$ cnneal. 
TABLE. 5

RESULTS OF THERMAL CYCLING TESTS

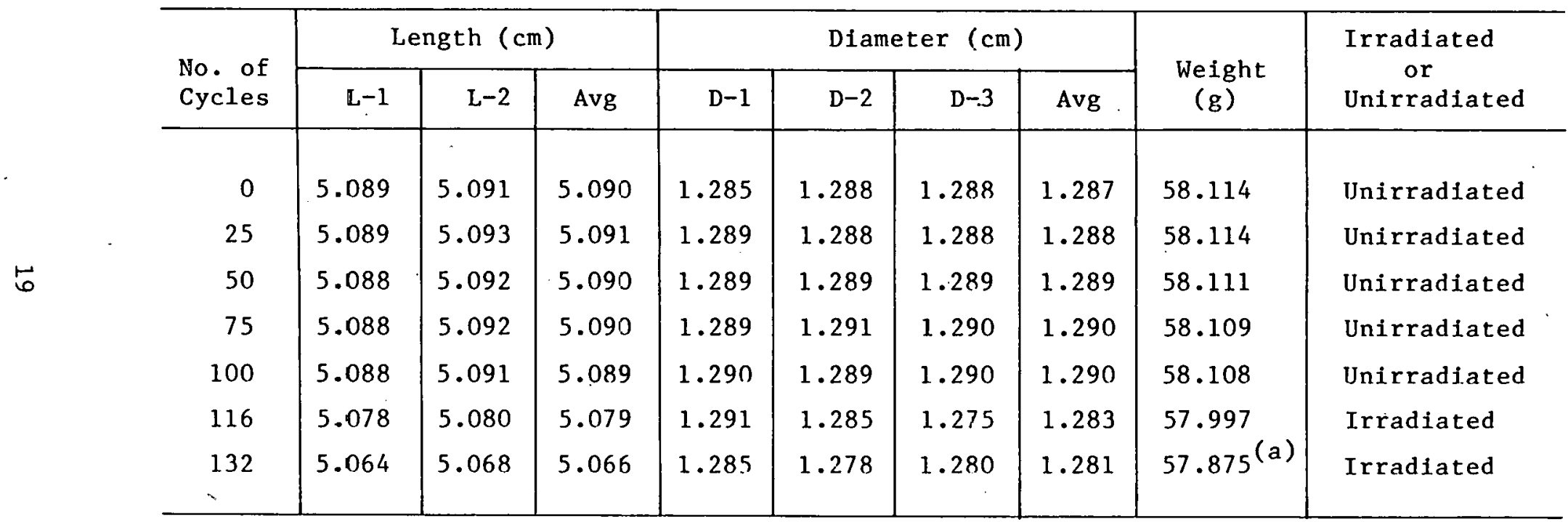

(a) Represents $0.4 \%$ loss in weight. 
Included in Table 5 are the results of cycling the same sample 32 times in the presence of neutrons. The sample was again dimensionally measured at the end of 16 and 32 cycles. The data show a small decrease in both length and diameter as well as a loss in weight.

After concluding the thermal cycling tests, the fuel sample was tested for fission product release characteristics at $1100^{\circ} \mathrm{C}$ and was found to give the same release fraction as sample E451-RI-A. 


\section{FISSION PRODUCT RELEASE CORRELATION}

The release of fission products from the fuel material comes about as the result of two processes: (1) through the recoil of fission fragments from the fuel surface into the free volume within the fuel element clad and (2) through a temperature-dependent diffusion-like release mechanism.

\subsection{RECOIL RELEASE}

For a cylindrical fuel region surrounded by a container (or clad), the recoil release fraction is

$$
\psi_{\mathrm{R}}=c\left(\frac{\Delta \mathrm{t}_{1}}{\mathrm{~h}}+\frac{4 \Delta \mathrm{t}_{2}}{\mathrm{~d}}\right)
$$

where. $\quad C=$ constant proportional to the ratio of the fission product range in the fuel to the range in the gap material,

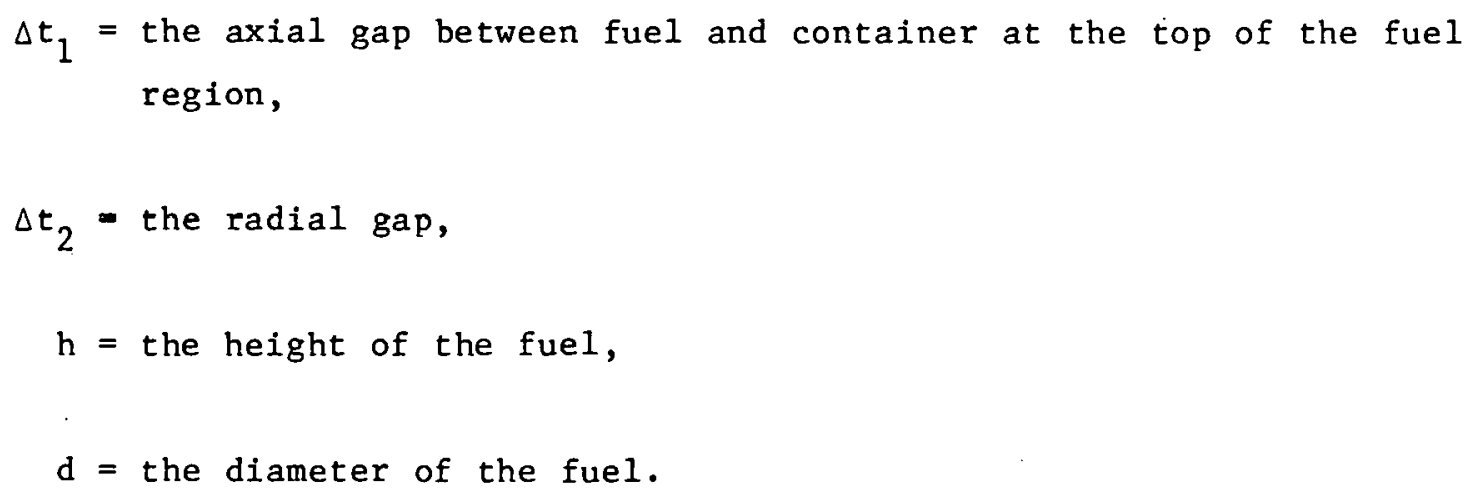
region,

The recoil release fraction has been measured in standard-size* TRIGA fuel elements (in 1960 and 1971) and was found to be $1.5 \times 10^{-5}$. Measurements have also been made with small-diameter (approximately $12.5-\mathrm{mm}$ ) samples of in.)

*Fuel 0.d. $\approx 36.45 \mathrm{~mm}(1.435 \mathrm{in.}) ;$ fuel-clad gap $\leq 0.064 \mathrm{~mm}(0.0025$ 
fuel (in 1966 and 1971) with 8.5 wt \% uranium ( $20 \%$ enriched) $\mathrm{ZrH}_{1.6}$ and in 1977-1978 with zirconium hydride fuel containing 8.5 wt \%, 30 wt \%, and 45 wt \% uranium. Results of the recoil release measurements done in 1971 (Ref. 1) are given in Table 6. These measurements were made with fuel specimens irradiated inside close-fitting stainless steel containers. In this experiment, the gas within the container was air.

In the current (1977-1978) experiment; the recoil release was measured with the fuel specimens in graphite crucibles (inside diameters of $15.9 \mathrm{~mm}$ and height of $57.2 \mathrm{~mm}$ ) in a helium atmosphere. The results of this experiment are given in Tulle 7 .

From these data and those in Table 6 , one can deduce a value for the constant $C$ in Eq. 2 for each sample and isotope, that is:

$$
c_{i j}=\psi_{i j} /\left(\frac{\Delta t_{1}}{h}+\frac{4 \Delta t_{2}}{d}\right)_{i} \text {, }
$$

for the ith specimen and the jth isotope. The mean value of the constant, $\overline{\mathrm{C}}$, is

$$
\bar{c}=\sum_{i=1}^{N_{1}} \sum_{j=1}^{N_{j}} c_{i . j} / N_{i} N_{j}
$$

For the 1971 experiment, $\bar{C}$ was found to be $2.20 \times 10^{-3}$; for the 1977-1978 experiment, $\bar{C}$ is $1.02 \times 10^{-4}$. However, since the constant $C$ is inversely proportional to the range of the fission products in the gas within the gap, the 1977-1978 experimental value of $\bar{C}$ may be normalized to an air gap by multiplying by $19 / 2.33$, the ratio of the range of fission fragments in heli.um to that in air. The value of $\bar{C}$ for an air-filled gap would then be $8.32 \times 10^{-4}$. 
TABLE 6

RECOIL RELEASE MEASURED IN 1971 EXPERIMENT

\begin{tabular}{|c|c|c|c|c|c|c|c|c|c|}
\hline \multirow{2}{*}{$\begin{array}{l}\text { Specimen } \\
\text { No. }\end{array}$} & \multirow{2}{*}{$\begin{array}{l}\text { Height } \\
\text { (mm) }\end{array}$} & \multirow{2}{*}{$\begin{array}{l}\text { Axial } \\
\text { Gap } \\
\text { (mm) }\end{array}$} & \multirow{2}{*}{$\begin{array}{l}\text { D1am } \\
\text { (mm) }\end{array}$} & \multirow{2}{*}{$\begin{array}{c}\text { Radial } \\
\text { Gap } \\
(\mathrm{mm})\end{array}$} & \multicolumn{5}{|c|}{ Release Fraction } \\
\hline & & & & & $\mathrm{Kr}-85 \mathrm{~m}$ & $\mathrm{Kr}-87$ & $\mathrm{Kr}-88$ & $\mathrm{Xe}-133$ & $\mathrm{Xe}-135$ \\
\hline 1 & 25.48 & 0.076 & 12.01 & 0.279 & $1 \cdot 31-4^{(a)}$ & $6.91-5$ & $9.78-5$ & $4 \cdot 98-5$ & $1.14-4$ \\
\hline 2 & 25.53 & 0.076 & 12.07 & 0.152 & $9.60-5$ & - & $7.13-5$ & $4.42-5$ & $8.67-5$ \\
\hline 3 & 25.53 & 0.025 & 12.04 & 0.102 & $9.50-5$ & -- & $7.10-5$ & $4.00-5$ & $8.73-5$ \\
\hline 4 & 25.96 & 0 & 11.96 & 0.305 & $1.67-4$ & - & $1.32-4$ & $6.70-5$ & $1.45-5$ \\
\hline 5 & 25.22 & 0.118 & 9.17 & 0.114 & $2.62-4$ & $1.50-4$ & $2.22-4$ & $6.06-5$ & $1.58-4$ \\
\hline
\end{tabular}

a) $1.31-4=1.31 \times 10^{-4}$

TABLE 7

RECOIL RELEASE MEASURED IN CURRENT (1977-1978) EXPERIMENT

\begin{tabular}{|c|c|c|c|c|c|c|c|}
\hline \multirow[b]{2}{*}{ Specimen } & \multirow{2}{*}{$\begin{array}{c}\text { Wt \% } \\
\text { Uranium }\end{array}$} & \multirow{2}{*}{$\begin{array}{l}\text { Height } \\
(\mathrm{mm})\end{array}$} & \multirow{2}{*}{$\begin{array}{l}\text { Diam } \\
(\mathrm{mm})\end{array}$} & \multicolumn{4}{|c|}{ Release Fraction } \\
\hline & & & & $\mathrm{Kr}-85 \mathrm{~m}$ & $\mathrm{Kr}-87$ & $\mathrm{Kr}-88$ & $\mathrm{Kr}-89$ \\
\hline $62177-\mathrm{R} 2$ & 8.5 & 51.1 & 11.2 & $1.02-4^{(a)}$ & $7 \cdot 45-5$ & $8.84-5$ & $3.53-5$ \\
\hline D167-R3 & 30 & 49.5 & 11.0 & $1.30-4$ & $8.01-5$ & $8.75-5$ & $2.63-5$ \\
\hline D167-R5-? & 30 & 49.1 & 11.1 & $1.12-4$ & $8.67-5$ & $1.02-4$ & $5.22-5$ \\
\hline D168-R1 & 45 & 49.4 & 11.1 & $1.06-4$ & $8.30-5$ & $8.13-5$ & $2.72-5$ \\
\hline D168-R1-L & 45 & 50.5 & 11.4 & $9.18-5$ & -- & $7.45-5$ & $3.77-5$ \\
\hline E451-R1-A & 45 & 49.9 & 11.2 & $5.57-5$ & $4.41-5$ & $4.86-5$ & $2.70-5$ \\
\hline
\end{tabular}

$$
\text { (a) } 1.102-4=1.02 \times 10^{-4}
$$


An additional measurement was made in the 1977-1978 experiment in which a specimen of about the size of those listed in Table 6 was placed inside a stainless steel container and irradiated. The gap between the container and the specimen was $0.125 \mathrm{~mm}$. From measurement of the release fraction of three isotopes ( $\mathrm{Kr}-85 \mathrm{~m}, \mathrm{Xe}-133$, and $\mathrm{Xe}-135)$, the value of $\overline{\mathrm{C}}$ is found to be $6.77 \times 10^{-4}$.

In the 1971 experiment, the release was also measured in an essentially full-size standard TRIGA fuel element. The release fraction was found to be $1.6 \times 10^{-5}$. Using the largest and smallest of the three values of $\bar{C}$ determined above, the radial gap for the full-size element, from this measurement, would be between $0.064 \mathrm{~mm}$ and $0.208 \mathrm{~mm}$.

For standard-size TRIGA fuel, using the largest value of $\bar{C}(2.2 \mathrm{x}$ $\left.10^{-3}\right)$, a gap thickness of $0.064 \mathrm{~mm}(0.0025 \mathrm{in}$, a conservatively large value for production fuel elements), and a diameter of $36.45 \mathrm{~mm}$ (1.435 in.), the recoil release fraction is

$$
\begin{aligned}
\psi_{R} & =\left(2.2 \times 10^{-3}\right)(4)\left(2.5 \times 10^{-3} / 1.435\right) \\
& =1.5 \times 10^{-5} .
\end{aligned}
$$

For the fuel elements in the 16-element and 25-element clusters, with a fuel diameter of $12.9 \mathrm{~mm}(0.508 \mathrm{in} \cdot)$, the manufacturing tolerances require that the fuel-clad gap be less than $0.0318 \mathrm{~mm}(0.00125 \mathrm{in.})$. If, for the purpose of the fission product release calculations, it is assumed that the gap is proportional to the diameter of the fuel for all size elements, the gap for the small-diameter fuel elements would be $(0.0635 \mathrm{~mm})(0.508 / 1.435)$ - $0.0229 \mathrm{~mm}$. Thus, it is reasonable to use the recoil rclcasc valuc of $1.5 \times 10^{-5}$ for all eypco of fucl elements based on the assumptions and conservatisms already assumed. 


\subsection{DIFFUSION RELEASE}

At high temperatures, above $400^{\circ}$ to $500^{\circ} \mathrm{C}$, the release fraction increases exponentially with increasing temperature. This increase in the release fraction with temperature suggests a diffusion-like release mechanism. However, the treatment of the migration of fission gases in the solid uranium-zirconium hydride as a classical diffusion process is not valid. These gases have very low solubility in solids and will nucleate and form bubbles in the matrix. The migration of the bubbles (by surface diffusion, vaporization, condensation, or solution processes) under thermal gradients is the controlling mechanism. Thus, the time-dependent release of fission product gases in metals has been observed (Ref. 3) to consist of a rapid-release component suggesting the migration (diffusion) of individual atoms and a slow-release component that may be a composite of the migration (diffusion) of clustered atoms. As the release fraction was not measured as a function of time during irradiation in this experiment, the separation of these components was not possible. However, since the irradiation times were relatively short, the predominant effect measured was the rapid-release mechanism; therefore, one overestimates the release for long irradiations.

The differential equation describing a classical diffusion process under equilibrium conditions of a radioactive nuclide in a medium in which the diffusing nuclide is being removed through radioactive decay at a rate proportional to $i$ ts concentration is

$$
D(T) \nabla^{2} n(\vec{r})-\lambda n(\vec{r})+P=0,
$$

where $D(T)=$ a temperature-dependent diffusion coefficient $\left(\mathrm{cm}^{2} / \mathrm{sec}\right)$,

$$
\begin{aligned}
n(\vec{r}) & =\text { the concentration of the diffusing material at } \vec{r}\left(n / \mathrm{cm}^{3}\right), \\
\lambda & =\text { the radioactive decay constant (sec), } \\
P & =\text { the production rate }\left(n / \mathrm{cm}^{3}-\mathrm{sec}\right) .
\end{aligned}
$$


Assuming spherical geometry, the solution of this equation is

$$
n(\vec{r})=P / \lambda-a \frac{\sinh (\lambda / D)^{1 / 2} r}{r}
$$

or

$$
n(\vec{r})=n(\vec{u})=P / \lambda-a(\lambda / D)^{1 / 2} \frac{\sinh u}{u}
$$

where $\mathrm{u}=(\lambda / C)^{1 / 2} \mathrm{r}$. The constant $\mathrm{a}$ is found by setting $\mathrm{n}=0$ at $\mathrm{u}=$ $u_{0}=\left(\lambda / D^{1 / 2} r_{0}\right.$, where $r_{0}=$ the radius of the sphere so that

$$
a=\frac{P / \lambda}{(\lambda / D)^{1 / 2} \frac{\sinh u_{0}}{u_{0}}}
$$

and

$$
\mathrm{n}=\frac{\mathrm{P}}{\lambda}\left[1-\frac{(\sinh \mathrm{u}) / \mathrm{u}}{\left(\sinh \mathrm{u}_{0}\right) / \mathrm{u}_{0}}\right]^{-}
$$

The rate at which nuclei are diffusing across the boundary of the sphere is

$$
-D \int_{A} \nabla n\left(r_{0}\right) d A=\frac{-3 P}{u_{0}^{2}}\left[1-u_{0} \operatorname{coth} \dot{u}_{0}\right] v,
$$

where $\mathrm{V}$ is the volume of the sphere. The rate of production is simply

$$
\int_{V} P d V=P V
$$


Therefore, the release fraction, $F_{\infty}$, of the nuclei produced in the sphere that diffuse from the surface under steady-state conditions is

$$
F_{\infty}=\frac{\int_{A} D \nabla n\left(r_{0}\right) d A}{\int_{r} P d V}=\frac{3\left(u_{0} \operatorname{coth} u_{0}-1\right)}{u_{0}^{2}} \text {, }
$$

where $u_{0}=(\lambda / D)^{1 / 2} r_{0}$.

The experimentally observed fractional release can be expressed by the equation derived by Frank (Ref. 4):

$$
F_{t}=F_{\infty}-\frac{2}{3 \pi^{2}}\left(1-e^{-\lambda t}\right) e^{-\lambda t} \sum_{n=1}^{\infty} \frac{1-e^{-\left(n^{2} \pi^{2} \frac{D t}{r_{0}^{2}}\right)}}{n^{2}\left(\frac{n^{2} \pi^{2} D}{\lambda r_{0}^{2}}\right)+1} .
$$

Values of the function

$$
G\left(\frac{D t}{r_{0}^{2}}, \frac{\lambda r_{0}^{2}}{D}\right)=\frac{\left(1-e^{-\lambda t}\right)}{3} F_{t}
$$

have been derived by Beck (Ref. 5) and are found in Table 9.7 of Ref. 6 .

The fractional release of a specific isotope at infinite time is found by first solving Eq. 14 for the diffusion coefficient, D, and then using the result in Eq. 12 to find the steady-state release fraction, $F_{\infty}$. 
In Table 8 the measured release fraction, $F_{t}$ (from Table 2), at fuel temperatures above $400^{\circ} \mathrm{C}$ has been corrected to reflect the fractional release one would expect for infinite exposure time, $F_{\infty}$. These data, as well as data acquired in an earlier experiment (Ref. 7) for 8.5 wt \%, $20 \%$ enriched $\mathrm{U}_{-\mathrm{ZHH}_{1.6}}$, are plotted in Figs. 6 through 8 for 8.5 wt. \% $\mathrm{U}-\mathrm{ZrH}_{1.6}$, 30 wt $\% \mathrm{U}-\mathrm{ZrH}_{1.6}$, and 45 wt $\% \mathrm{U}-\mathrm{ZrH}_{1.6}$, respectively.

In addition to the data points shown in Figs. 6 through 8 , there is a plotted curve which represents the fission product release fraction (by diffusion) as used in safety analyses for TRIGA reactors. It is described by the relationship

$$
\psi_{D}=\left(3.6 \times 10^{3}\right)\left(e^{-1.34 \times 10^{4} / \mathrm{T}}\right)
$$

where $\mathrm{T}=$ fuel temperature $\left({ }^{\circ} \mathrm{K}\right)$. This exponential function was chosen to be a conservative representation of the measured fission product release data. It can be seen that essentially all of the measured release fractions lie below the curve calculated through Eq. 15.

It is also interesting to note that all of the values for the release fraction of $\mathrm{Kr}-8 \mathrm{~g}$ are at leat a factor of 2.5 below the value caleulated through Eq. 15. As the half-life of $\mathrm{kr}-89$ is small (3.2 min) compared with the irradiation time ( $30 \mathrm{~min})$, the measured release fraction is, in fact, the infinite time release fraction.

\subsection{EFFECT OF EXPERIMENTAL CONDITIONS ON HIGH-TEMPERATURE RELEASE}

Examination of Figs. 6 through 8 clearly shows that a diffusion release model does not have the correct shape to describe the experimental results accurately over the temperature range of interest (approximately $400^{\circ}$ to $1100^{\circ} \mathrm{C}$ ). The expression used to predict the fission product release fraction (Eq. 15) greatly overestimates the release in the middle temperature range $\left(600^{\circ}\right.$ to $\left.900^{\circ} \mathrm{C}\right)$. 
TABLE 8

HIGH-TEMPERATURE RELEASE FRACTION CORRECTED TO INFINITE TIME

\begin{tabular}{|c|c|c|c|c|c|c|c|}
\hline \multirow[b]{2}{*}{ Specimen } & \multirow{2}{*}{$\begin{array}{c}\text { Wt \% } \\
\text { Uranium }\end{array}$} & \multirow{2}{*}{$\begin{array}{c}\text { Percent } \\
\text { Enrichment }\end{array}$} & \multirow{2}{*}{$\begin{array}{l}\text { Irradi- } \\
\text { ation } \\
\text { Temp } \\
\left({ }^{\circ} \mathrm{C}\right)\end{array}$} & \multicolumn{4}{|c|}{$\mathrm{F}_{\infty}$} \\
\hline & & & & $\mathrm{Kr}-85 \mathrm{~m}$ & $\mathrm{Kr}-87$ & $\mathrm{Kr}-88$ & $\mathrm{Kr}-89$ \\
\hline D167-R3 & 30 & D & $\begin{array}{r}800 \\
1100\end{array}$ & $\begin{array}{l}1.06 \times 10^{-3} \\
2.70 \times 10^{-1}\end{array}$ & $\begin{array}{l}4.00 \times 10^{-4} \\
9.27 \times 10^{-2}\end{array}$ & $\begin{array}{l}4.31 \times 10^{-4} \\
8.25 \times 10^{-2}\end{array}$ & $\begin{array}{l}1.03 \times 10^{-4} \\
1.88 \times 10^{-2}\end{array}$ \\
\hline D168-R1 & 45 & D & $\begin{array}{r}800 \\
1100\end{array}$ & $\begin{array}{l}1.66 \times 10^{-3} \\
5.47 \times 10^{-2}\end{array}$ & $\begin{array}{l}5.63 \times 10^{-4} \\
5.84 \times 10^{-3}\end{array}$ & $\begin{array}{l}5.73 \times 10^{-4} \\
4.25 \times 10^{-3}\end{array}$ & $\begin{array}{l}1.10 \times 10^{-4} \\
9.69 \times 10^{-4}\end{array}$ \\
\hline D168-R1-1 & 45 & 0 & $\begin{array}{r}800 \\
1100\end{array}$ & $\begin{array}{l}8.31 \times 10^{-4} \\
5.36 \times 10^{-3}\end{array}$ & $\begin{array}{l}3.39 \times 10^{-4} \\
9.41 \times 10^{-4}\end{array}$ & $\begin{array}{l}3.86 \times 10^{-4} \\
8.65 \times 10^{-4}\end{array}$ & $\begin{array}{l}8.90 \times 10^{-5} \\
1.92 \times 10^{-4}\end{array}$ \\
\hline
\end{tabular}




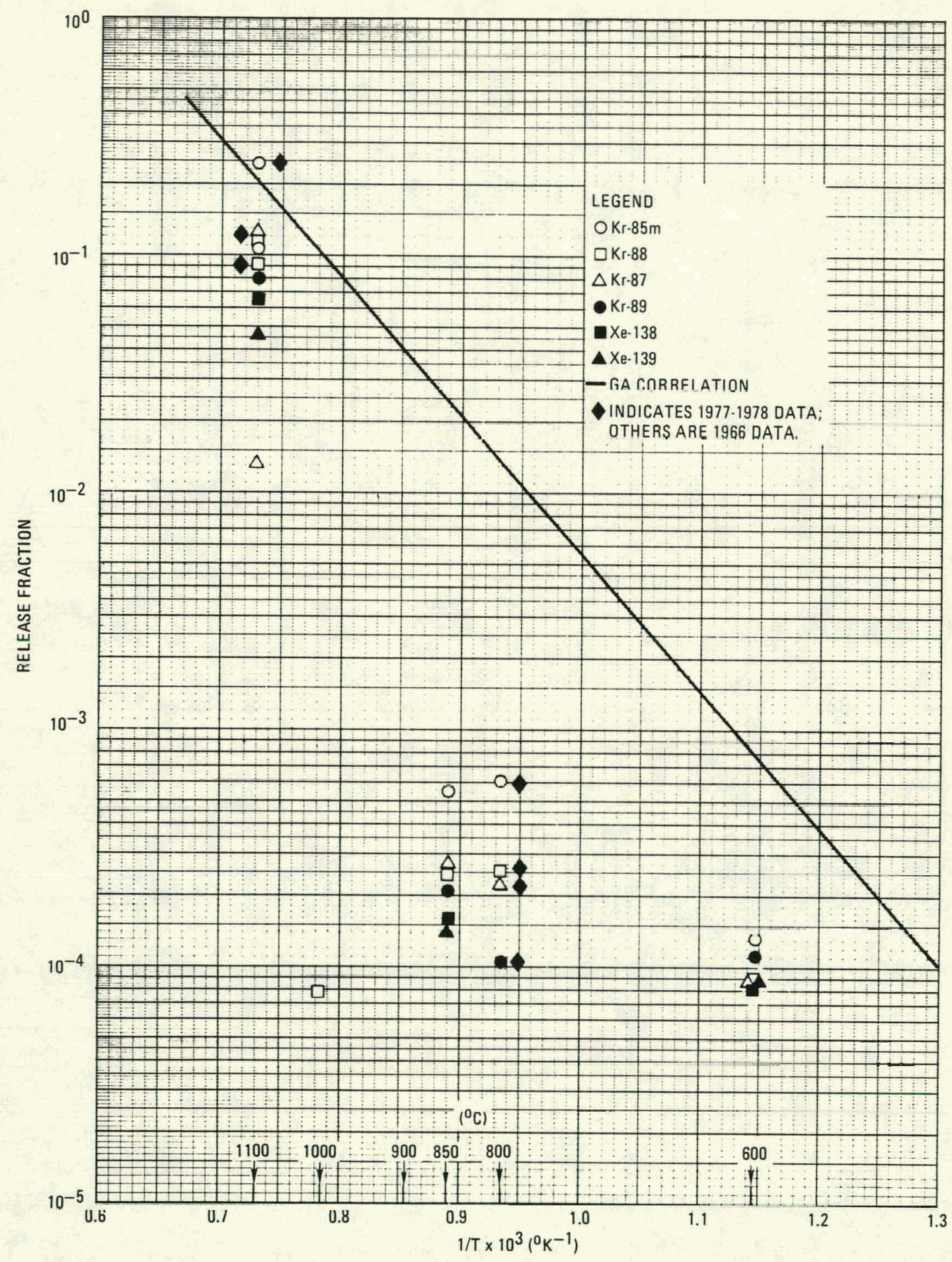

$E L-3977$

Fig. 6. Release fraction vs reciprocal temperature for 8.5 wt \% U-ZrH 1.6 


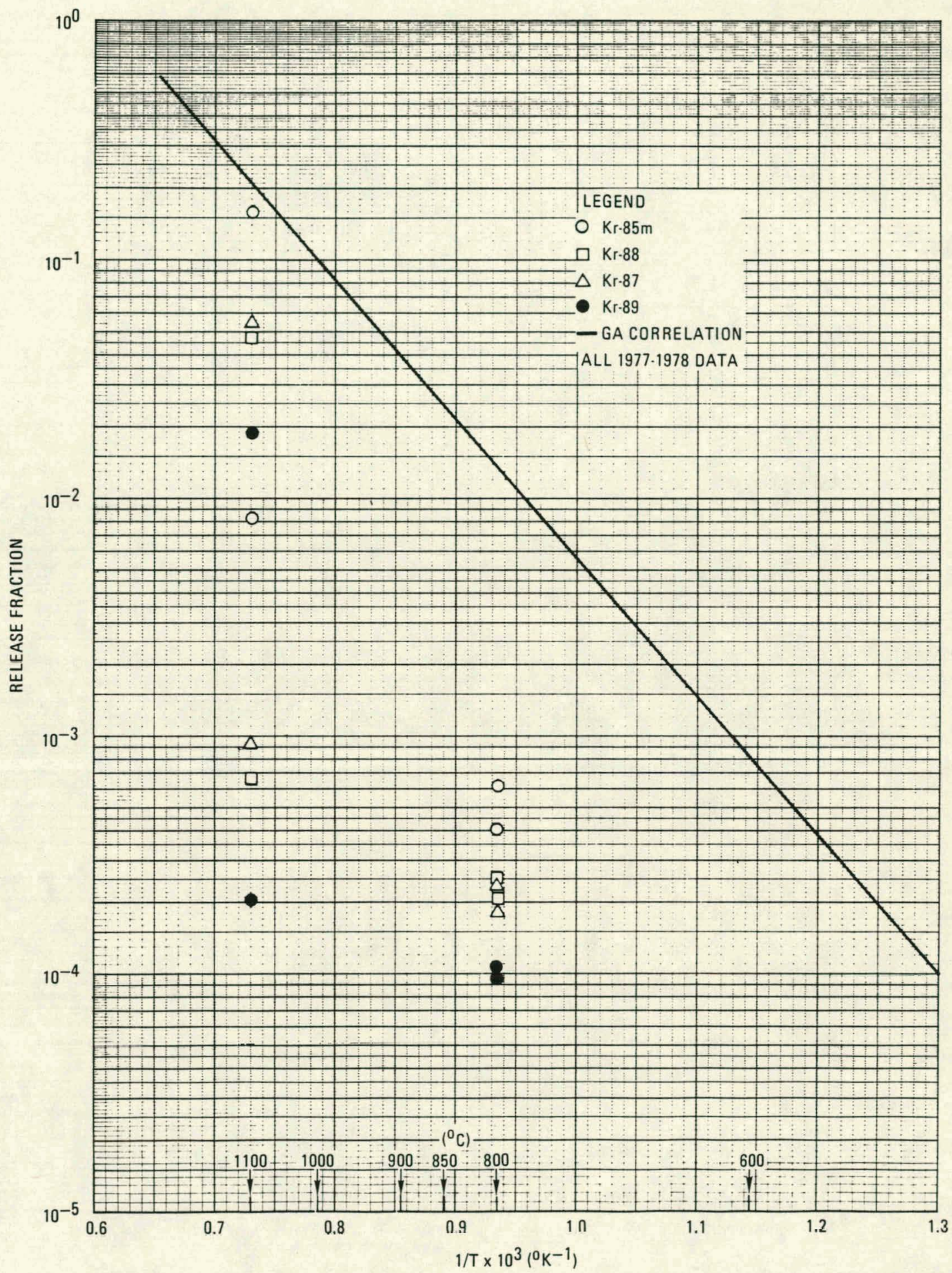

$E L-3978$

Fig. 7. Release fraction vs reciprocal temperature for 30 wt \% U-ZrH 1.6 


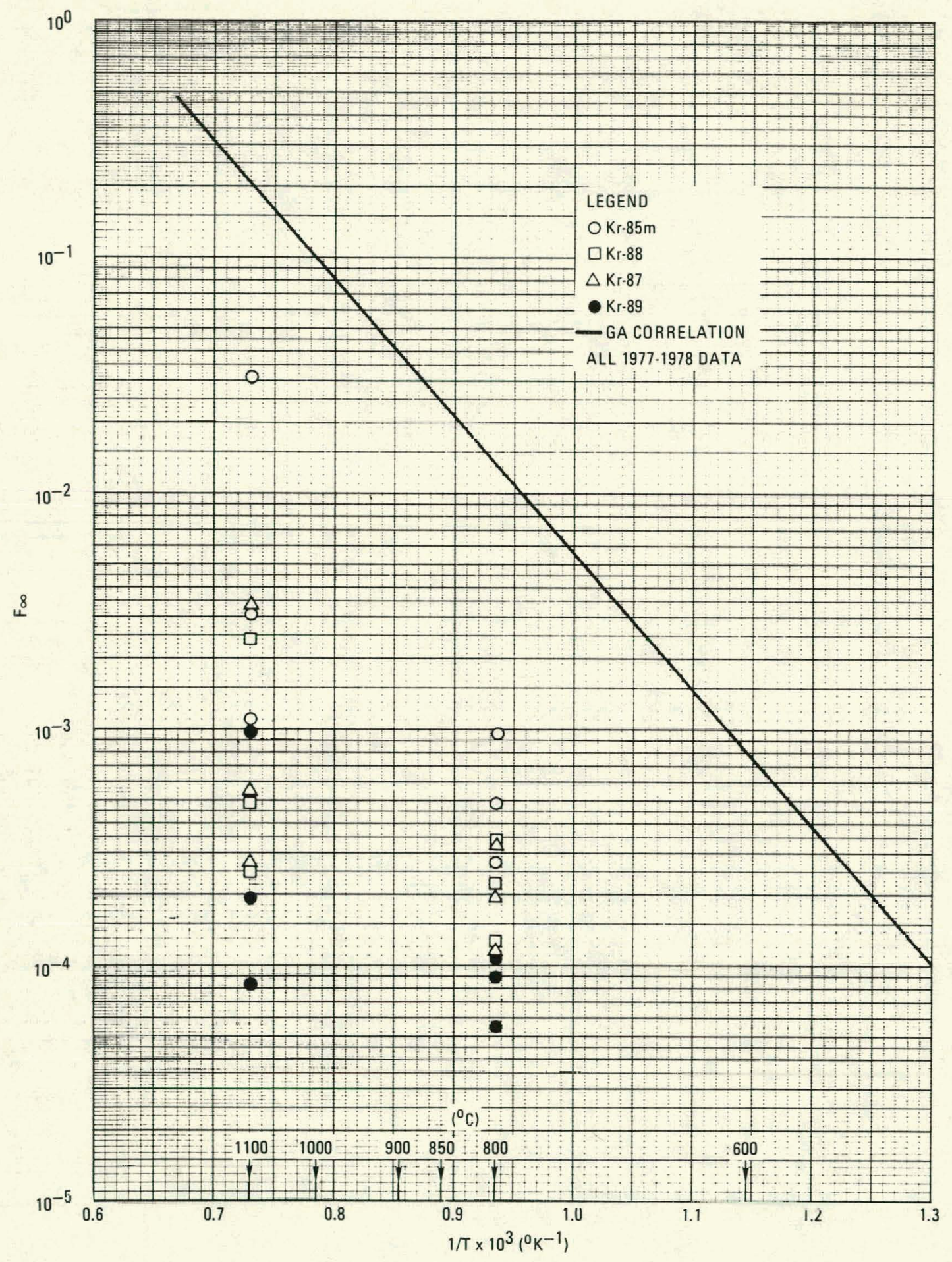

$E L-3979$

Fig. 8. Release fracliun vs reciprocal temperature for 45 wt \% U-ZrH 1.6 
It is important to recognize that the values derived from empirical data apply only to the experimental conditions. Because no attempt was made or could have been made to maintain the partial pressure of hydrogen over the $\mathrm{U}-\mathrm{ZrH}_{1.6}$ at the equilibrium value for the temperature of the samples, the higher-temperature samples were dehydrided during the 1/4- to 1 -hr irradiation periods. Thus, the sample irradiated at $1100^{\circ} \mathrm{C}$ was quickly dehydrided, and the migration (diffusion) of the fission product gases was therefore characteristic of migration (diffusion) in an alloy of uranium and zirconium. At some lower temperature, the dehydriding was occurring at a rate comparable to the rate at which the migration (diffusion) process was allowing the escape of fission gases. At still lower temperatures, the hydrogen escape rate was so low that the measured migration (diffusion) of the fission gases is truly characteristic of uranium-zirconium hydride. Nevertheless, it is probable that the release rate in the open structure of dehydrided uranium-zirconium hydride is much higher than the rate in the closed structure of well-hydrided uraniumzirconium hydride. Thus, use of these experimental data to extrapolate to the conditions existing in a closed system, such as a sealed, clad fuel element, is probably conservative.

On the other hand, one might question the application of these data to a situation in which hydrogen is suddenly released from fuel material in which a substantial inventory of fission products had already been built in, such as the rupture of a fuel element clad when the fuel is at elevated temperatures. Under such conditions, it might be argued that the sudden release of hydrogen from the fuel might sweep the fission product gases before it. However, if one considers the results of the postirradiation annealing experiments shown in Fig. 1, one could conclude that this sweeping does not occur.

\subsection{EFFECT OF URANIUM PARTICLE SIZE ON HIGH-TEMPERATURE RELEASE}

As reported in Section 3, microprobe examination of the fuel samples revealed microsegregation of uranium in fuel containing higher uranium loading. Because of the higher localized concentration of uranium as the 
maximum weight fraction increases, it is postulated that the fission gas release is lowered at high temperature as a result of trapping of the recoiled fragments in the uranium. In the low wt \% samples, the uranium is finely dispersed so that a fission fragment born in the uranium will have a high probability of recoiling out of the uranium particle into the $\mathrm{ZrH}$ matrix through which it will diffuse. As the uranium particles increase in size, with higher loadings, the probability of recoiling out of the uranium particle decreases and fewer fragments are deposited in the $\mathrm{ZrH}$. It was also found that the particle size or degree of microsegregation of uranium varied widely for a given uranium loading.

This change in the uranium atom distribution does not affect the lowtemperature release, as the probability that a fission fragment will be born within a recoil range of the surface is unchanged. Thus, the fission gas release at high temperature $\left(1100^{\circ} \mathrm{C}\right)$ was found to decrease with increasing uranium content and to remain essentially unchanged at temperatures below $400^{\circ} \mathrm{C}$. 


\section{CONCLUSIONS}

The data for fission product release from TRIGA-LEU fuels acquired in the experiments described herein agree well with data from similar experiments reported in 1968 (Ref. 7) and 1971 (Ref. 1). The release was determined to be predominantly recoil-controlled at temperatures of $\leq 400^{\circ} \mathrm{C}$ and controlled by a migration or diffusion-like process above $400^{\circ} \mathrm{C}$. Lowtemperature release appears to be independent of uranium loadings, but the high-temperature release seems to decrease with increasing weight fractions of uranium. The correlation used to calculate the release of fission products from TRIGA fuel is

$$
\psi=\left(1.5 \times 10^{-5}\right)+\left(3.6 \times 10^{3}\right)\left(\mathrm{e}^{-1.34 \times 10^{4} / \mathrm{T}}\right)
$$

where $\mathrm{T}=$ fuel temperature $\left({ }^{\circ} \mathrm{K}\right)$.

It is applicable for the high-uranium-loaded (TRIGA-LEU) fuels as well as the 8.5 wt \% U-ZrH fuel for which it was originally derived. This correlation predicts higher fission product releases than measurements would indicate up to $1100^{\circ} \mathrm{C}$. At normal TRIGA operating temperatures $\left(<750^{\circ} \mathrm{C}\right)$, there is a safety factor of approximately 4 between predicted values (by Eq. 1) and experimentally deduced values.

With the exception of $I-135$ and $\mathrm{Xe}-135$, the results of postirradiation anneal tests on a sample containing a high uranium loading (45 wt \%) was within a factor of 2 of earlier data for the $400^{\circ} \mathrm{C}$ anneal. The effect on fission product release of annealing the preirradiated fuel at $400^{\circ} \mathrm{C}$ appears to be an increase (at least for short times). For the higher temperature anneal $\left(800^{\circ} \mathrm{C}\right)$, the release fraction was still lower than the value given by the correlation used to represent fission product release from TRIGA fuel (Eq. 1). 
The results of the thermal cycling tests show the excellent physical stability exhibited by the high-uranium-loaded ( $45 \mathrm{wt} \%$ ) fuel. The thermal cycling tests were performed over the temperature range of $500^{\circ}$ to $725^{\circ} \mathrm{C}$. There were no significant changes in dimensions in the out-of-pile tests, and a small decrease in weight was measured. The in-pile cycling test showed a small decrease in both length and diameter, which may be related to a loss of hydrogen during this test. In these thermal cycling tests, the sample traversed a phase transformation temperature of the uranium (orthorhombic to tetragonal at $653^{\circ} \mathrm{C}$ ). The structure consisting of a fine dispersion of the uranium in a still largely ( 80 vol \%) zirconium hydride matrix precludes anisotropic growth from taking place as a result of cycling through the phase transformation temperature, since the hydride matrix restrains the uranium particles and accommodates the transformation stresses and strains.

The results of the microprobe studies indicate that the uranium in the 45 wt \% uranium samples is uniformly distributed on a macroscale, but it has segregated in the interdendritic regions of the cast structure. This leads to a relatively coarser grain size than in the 8.5 wt \% samples, but the uranium is still in the form of a dendritic, broken-up structure surrounded by the hydride matrix. Such a structure would be expected to exhibit the dimensional stability that was observed in the thermal cycling tests. Tt alsn lears th the type of firgion product relcaoc deocribed in an earlier section. 


\section{REFERENCES}

1. Langer, S., and N. L. Baldwin, "Fission Product Release Experiments on Uranium-Zirconium Hydride Fuels," General Atomic Report Gulf-GA-A10781, September 1971; see also F. C. Foushee and R. H. Peters, "Summary of TRIGA Fuel Fission Product Release Experiments," General Atomic Report Gulf-EES-A10801, September 1971.

2. Anderson, E. E., et al., "An In-Core Furnace for the High-Temperature Irradiation Testing of Reactor Fuels," Nucl. Techol., 11, 259-265 (June 1971).

3. Bauer, A. A., et al., "The Migration of Fission Products in Au, $\mathrm{Zr}$, $\mathrm{Fe}-20$ wt \% $\mathrm{Cr}$, and $\mathrm{Fe}-29$ wt \% Ni-13 wt \% $\mathrm{Cr}$," Battelle Memorial Institute Report BMI-1696, October 1964.

4. Eichenberg, J. D., et al., "Fuel Element Conference, Paris, France, November 18-23, 1957," USAEC Report TID 7546, 1958, pp. 616-716.

5. Beck, S. D., "The Diffusion of Radioactive Fission Products from Porous Fuel Elements," Battelle Memorial Institute Report BMI-1433, 1960.

6. Belle, J. (ed.), Uranium Dioxide: Properties and Nuclear Applications, Naval Reactors, Division of Reactor Development, USAEC, Washington, D. C., 1961 .

7. Foushee, F. C., "Release of Rare Gas Fission Products from U-ZrH Fuel Material," General Atomic Report GA-8597, March 29, 1968. 